\title{
Is there a rapid increase in prevalence of obesity in Polish children? An 18-year prospective observational study in Gdansk, Poland
}

Michał Brzeziński ${ }^{1}$, Marek Jankowski², Agnieszka Jankowska³, Aleksandra Niedzielska², Barbara Kamińska ${ }^{3}$

\author{
${ }^{1}$ Department of Public Health and Social Medicine, Medical University of Gdansk \\ Gdansk, Poland \\ ${ }^{2}$ Gdansk Center for Health Promotion, Gdansk, Poland \\ ${ }^{3}$ Department of Pediatrics, Pediatric Gastroenterology, Hepatology and Nutrition, \\ Medical University of Gdansk, Gdansk, Poland
}

Submitted: 7 March 2017

Accepted: 2 May 2017

Arch Med Sci 2018; 14, 1: 22-29

DOI: https://doi.org/10.5114/aoms.2018.72239

Copyright (c) 2017 Termedia \& Banach

\section{Abstract}

Introduction: The prevalence of overweight and obesity is not regularly screened among Polish children. Very few longitudinal data exist on the prevalence and increase of overweight and obesity in this population. The aim of the study was to analyze the prevalence of overweight and obesity among selected age categories of children from Gdansk, on the basis of 1992-2012 data.

Material and methods: The anthropometric data (body weight and height, body mass index) of 70,329 children aged between 6 and 13 years were analyzed. Data were collected during annually performed child health measurements in schools by medical staff of Gdansk Center for Health Promotion during 1992-2012.

Results: No constant trend to increase or decrease in the prevalence of overweight or obesity was documented in any of the studied age groups $(p>0.05)$. An age-related increase in the prevalence of overweight and obesity was observed throughout all consecutive age categories in boys and in prepubertal girls $(p<0.05)$. Overweight and obesity were significantly more frequent in girls than in boys from all age categories $(p<0.05)$, except 12 - and 13 -yearold children $(p=0.173 ; p=0.973)$, in whom no gender-specific differences were documented.

Conclusions: Our study did not confirm the previously reported growing tendency in the prevalence of overweight and obesity among children. However, our findings point to an age-related increase in the prevalence of excess body weight in the pediatric population.

Key words: excess body weight, percentile charts, secular trends.

\section{Introduction}

Decades of comparisons between the anthropometric indices of individuals of the same age and gender revealed the phenomenon of developmental acceleration, which is also referred to as a secular trend [1]. While inhibition has already been documented in some Northern European countries, the secular increase in attained height still continues in Southern and Central Europe [2, 3]. Postulated reasons behind these discrepancies and causes of the observed deceleration include the

\author{
Corresponding author: \\ Michał Brzeziński MD, PhD \\ Department of Public \\ Health and \\ Social Medicine \\ Medical University \\ of Gdansk \\ al. Zwyciestwa 42 a \\ 80-210 Gdansk, Poland \\ Phone: +4858 3491540 \\ Fax: +48 583491548 \\ E-mail: brzezinski@gumed. \\ edu.pl
}


negative influence of compounds present in the environment and foods [4], and the effects of environmental and family stressors [5].

Apart from the secular trend documented in children and adolescents, an increase in body fatness and weight of individuals from this age category can be observed during recent decades [6]. This is reflected by increasing prevalence of overweight and obesity among both children and adults.

\section{Epidemiology of overweight and obesity worldwide and in Poland}

Irrespective of diagnostic criteria [7-9], a considerable increase in the number of individuals with excess body fatness can be observed in re- cent years $[10,11]$. Due to the improvement in global economic status, this problem affects an increasing number of individuals in all social groups [12]. After the collapse of the Communist Bloc, a radical improvement in socioeconomic conditions (including the availability of highly energetic foodstuffs) and lifestyle was observed in Poland as well $[13,14]$. However, this was reflected by an increased number of overweight and obese individuals [15].

Like in adults, the emerging epidemic of overweight and obesity is observed among children and adolescents as well [16]. Nevertheless, a number of reports published during the last 5 years suggest that the upward tendency in the prevalence of obesity in highly developed coun-

Table I. Basic characteristics of studied population, stratified according to children's age and year of examination

\begin{tabular}{|c|c|c|c|c|c|c|c|c|c|}
\hline \multirow[t]{2}{*}{ Year } & \multicolumn{8}{|c|}{ Year of birth } & \multirow[t]{2}{*}{ Total } \\
\hline & 6 years & 7 years & 8 years & 9 years & 10 years & 11 years & 12 years & 13 years & \\
\hline 1986 & $\begin{array}{c}0 \\
(0 \%)\end{array}$ & $\begin{array}{c}9 \\
(0.04 \%)\end{array}$ & $\begin{array}{c}12 \\
(0.59 \%)\end{array}$ & $\begin{array}{c}6 \\
(0.13 \%)\end{array}$ & $\begin{array}{c}25 \\
(0.48 \%)\end{array}$ & $\begin{array}{c}22 \\
(0.42 \%)\end{array}$ & $\begin{array}{c}0 \\
(0 \%)\end{array}$ & $\begin{array}{c}0 \\
(0 \%)\end{array}$ & $\begin{array}{c}74 \\
(0.11 \%)\end{array}$ \\
\hline 1987 & $\begin{array}{c}223 \\
(1.2 \%)\end{array}$ & $\begin{array}{c}896 \\
(3.67 \%)\end{array}$ & $\begin{array}{c}31 \\
(1.53 \%)\end{array}$ & $\begin{array}{c}7 \\
(0.15 \%)\end{array}$ & $\begin{array}{c}2 \\
(0.04 \%)\end{array}$ & $\begin{array}{c}1 \\
(0.02 \%)\end{array}$ & $\begin{array}{c}0 \\
(0 \%)\end{array}$ & $\begin{array}{c}0 \\
(0 \%)\end{array}$ & $\begin{array}{c}1160 \\
(1.74 \%)\end{array}$ \\
\hline 1988 & $\begin{array}{c}962 \\
(5.18 \%)\end{array}$ & $\begin{array}{c}1418 \\
(5.81 \%)\end{array}$ & $\begin{array}{c}47 \\
(2.32 \%) \\
\end{array}$ & $\begin{array}{c}3 \\
(0.06 \%)\end{array}$ & $\begin{array}{c}1 \\
(0.02 \%)\end{array}$ & $\begin{array}{c}0 \\
(0 \%)\end{array}$ & $\begin{array}{c}0 \\
(0 \%)\end{array}$ & $\begin{array}{c}0 \\
(0 \%)\end{array}$ & $\begin{array}{c}2431 \\
(3.64 \%)\end{array}$ \\
\hline 1989 & $\begin{array}{c}1324 \\
(7.12 \%)\end{array}$ & $\begin{array}{c}1860 \\
(7.61 \%)\end{array}$ & $\begin{array}{c}14 \\
(0.69 \%)\end{array}$ & $\begin{array}{c}0 \\
(0 \%)\end{array}$ & $\begin{array}{c}0 \\
(0 \%)\end{array}$ & $\begin{array}{c}3 \\
(0.06 \%)\end{array}$ & $\begin{array}{c}0 \\
(0 \%)\end{array}$ & $\begin{array}{c}0 \\
(0 \%)\end{array}$ & $\begin{array}{c}3201 \\
(4.79 \%)\end{array}$ \\
\hline 1990 & $\begin{array}{c}1593 \\
(8.57 \%)\end{array}$ & $\begin{array}{c}2044 \\
(8.37 \%)\end{array}$ & $\begin{array}{c}14 \\
(0.69 \%)\end{array}$ & $\begin{array}{c}2 \\
(0.04 \%)\end{array}$ & $\begin{array}{c}1 \\
(0.02 \%)\end{array}$ & $\begin{array}{c}2 \\
(0.04 \%)\end{array}$ & $\begin{array}{c}0 \\
(0 \%)\end{array}$ & $\begin{array}{c}6 \\
(0.27 \%)\end{array}$ & $\begin{array}{c}3662 \\
(5.48 \%)\end{array}$ \\
\hline 1991 & $\begin{array}{c}1505 \\
(8.1 \%)\end{array}$ & $\begin{array}{c}2113 \\
(8.65 \%)\end{array}$ & $\begin{array}{c}1 \\
(0.05 \%)\end{array}$ & $\begin{array}{c}3 \\
(0.06 \%)\end{array}$ & $\begin{array}{c}5 \\
(0.1 \%)\end{array}$ & $\begin{array}{c}0 \\
(0 \%)\end{array}$ & $\begin{array}{c}4 \\
(0.09 \%)\end{array}$ & $\begin{array}{c}0 \\
(0 \%)\end{array}$ & $\begin{array}{c}3631 \\
(5.43 \%)\end{array}$ \\
\hline 1992 & $\begin{array}{c}1229 \\
(6.61 \%)\end{array}$ & $\begin{array}{c}573 \\
(2.35 \%)\end{array}$ & $\begin{array}{c}22 \\
(1.09 \%)\end{array}$ & $\begin{array}{c}9 \\
(0.19 \%)\end{array}$ & $\begin{array}{c}0 \\
(0 \%)\end{array}$ & $\begin{array}{c}5 \\
(0.1 \%)\end{array}$ & $\begin{array}{c}3 \\
(0.07 \%)\end{array}$ & $\begin{array}{c}3 \\
(0.14 \%)\end{array}$ & $\begin{array}{c}1844 \\
(2.76 \%)\end{array}$ \\
\hline 1993 & $\begin{array}{c}632 \\
(3.4 \%)\end{array}$ & $\begin{array}{c}1880 \\
(7.7 \%)\end{array}$ & $\begin{array}{c}15 \\
(0.74 \%)\end{array}$ & $\begin{array}{c}0 \\
(0 \%)\end{array}$ & $\begin{array}{c}11 \\
(0.21 \%) \\
\end{array}$ & $\begin{array}{c}2 \\
(0.04 \%)\end{array}$ & $\begin{array}{c}106 \\
(2.38 \%) \\
\end{array}$ & $\begin{array}{c}323 \\
(14.66 \%)\end{array}$ & $\begin{array}{c}2969 \\
(4.44 \%) \\
\end{array}$ \\
\hline 1994 & $\begin{array}{c}1918 \\
(10.32 \%)\end{array}$ & $\begin{array}{c}2494 \\
(10.21 \%)\end{array}$ & $\begin{array}{c}15 \\
(0.74 \%) \\
\end{array}$ & $\begin{array}{c}13 \\
(0.28 \%)\end{array}$ & $\begin{array}{c}3 \\
(0.06 \%)\end{array}$ & $\begin{array}{c}91 \\
(1.74 \%)\end{array}$ & $\begin{array}{c}656 \\
(14.73 \%)\end{array}$ & $\begin{array}{c}502 \\
(22.79 \%)\end{array}$ & $\begin{array}{c}5692 \\
(8.52 \%)\end{array}$ \\
\hline 1995 & $\begin{array}{c}2164 \\
(11.64 \%)\end{array}$ & $\begin{array}{c}2778 \\
(11.37 \%)\end{array}$ & $\begin{array}{c}9 \\
(0.44 \%)\end{array}$ & $\begin{array}{c}8 \\
(0.17 \%)\end{array}$ & $\begin{array}{c}82 \\
(1.58 \%) \\
\end{array}$ & $\begin{array}{c}649 \\
(12.39 \%)\end{array}$ & $\begin{array}{c}752 \\
(16.88 \%)\end{array}$ & $\begin{array}{c}357 \\
(16.21 \%)\end{array}$ & $\begin{array}{c}6799 \\
(10.17 \%)\end{array}$ \\
\hline 1996 & $\begin{array}{c}1496 \\
(8.05 \%) \\
\end{array}$ & $\begin{array}{c}683 \\
(2.8 \%) \\
\end{array}$ & $\begin{array}{c}18 \\
(0.89 \%) \\
\end{array}$ & $\begin{array}{c}84 \\
(1.78 \%) \\
\end{array}$ & $\begin{array}{c}610 \\
(11.77 \%) \\
\end{array}$ & $\begin{array}{c}718 \\
(13.71 \%) \\
\end{array}$ & $\begin{array}{c}680 \\
(15.27 \%) \\
\end{array}$ & $\begin{array}{c}289 \\
(13.12 \%) \\
\end{array}$ & $\begin{array}{c}4578 \\
(6.85 \%) \\
\end{array}$ \\
\hline 1997 & $\begin{array}{c}663 \\
(3.57 \%)\end{array}$ & $\begin{array}{c}1634 \\
(6.69 \%) \\
\end{array}$ & $\begin{array}{c}93 \\
(4.59 \%)\end{array}$ & $\begin{array}{c}664 \\
(14.09 \%)\end{array}$ & $\begin{array}{c}687 \\
(13.25 \%)\end{array}$ & $\begin{array}{c}666 \\
(12.72 \%)\end{array}$ & $\begin{array}{c}576 \\
(12.93 \%)\end{array}$ & $\begin{array}{c}408 \\
(18.52 \%)\end{array}$ & $\begin{array}{c}5391 \\
(8.07 \%)\end{array}$ \\
\hline 1998 & $\begin{array}{c}919 \\
(4.94 \%) \\
\end{array}$ & $\begin{array}{c}1764 \\
(7.22 \%) \\
\end{array}$ & $\begin{array}{c}374 \\
(18.48 \%)\end{array}$ & $\begin{array}{c}723 \\
(15.34 \%)\end{array}$ & $\begin{array}{c}624 \\
(12.04 \%)\end{array}$ & $\begin{array}{c}560 \\
(10.7 \%) \\
\end{array}$ & $\begin{array}{c}726 \\
(16.3 \%)\end{array}$ & $\begin{array}{c}294 \\
(13.35 \%)\end{array}$ & $\begin{array}{c}5984 \\
(8.95 \%) \\
\end{array}$ \\
\hline 1999 & $\begin{array}{c}1428 \\
(7.68 \%) \\
\end{array}$ & $\begin{array}{c}1895 \\
(7.76 \%) \\
\end{array}$ & $\begin{array}{c}269 \\
(13.29 \%) \\
\end{array}$ & $\begin{array}{c}620 \\
(13.16 \%) \\
\end{array}$ & $\begin{array}{c}618 \\
(11.92 \%) \\
\end{array}$ & $\begin{array}{c}908 \\
(17.34 \%) \\
\end{array}$ & $\begin{array}{c}367 \\
(8.24 \%) \\
\end{array}$ & $\begin{array}{c}21 \\
(0.95 \%) \\
\end{array}$ & $\begin{array}{c}6126 \\
(9.17 \%) \\
\end{array}$ \\
\hline 2000 & $\begin{array}{c}1585 \\
(8.53 \%) \\
\end{array}$ & $\begin{array}{c}1888 \\
(7.73 \%) \\
\end{array}$ & $\begin{array}{c}288 \\
(14.23 \%)\end{array}$ & $\begin{array}{c}638 \\
(13.54 \%)\end{array}$ & $\begin{array}{c}804 \\
(15.51 \%)\end{array}$ & $\begin{array}{c}723 \\
(13.81 \%)\end{array}$ & $\begin{array}{c}494 \\
(11.09 \%)\end{array}$ & $\begin{array}{c}0 \\
(0 \%)\end{array}$ & $\begin{array}{c}6420 \\
(9.61 \%)\end{array}$ \\
\hline 2001 & $\begin{array}{c}938 \\
(5.05 \%) \\
\end{array}$ & $\begin{array}{c}484 \\
(1.98 \%) \\
\end{array}$ & $\begin{array}{c}341 \\
(16.85 \%) \\
\end{array}$ & $\begin{array}{c}861 \\
(18.27 \%) \\
\end{array}$ & $\begin{array}{c}842 \\
(16.25 \%) \\
\end{array}$ & $\begin{array}{c}781 \\
(14.92 \%) \\
\end{array}$ & $\begin{array}{c}90 \\
(2.02 \%)\end{array}$ & $\begin{array}{c}0 \\
(0 \%)\end{array}$ & $\begin{array}{c}4337 \\
(6.49 \%)\end{array}$ \\
\hline 2002 & $\begin{array}{c}8 \\
(0.04 \%)\end{array}$ & $\begin{array}{c}6 \\
(0.02 \%)\end{array}$ & $\begin{array}{c}403 \\
(19.91 \%)\end{array}$ & $\begin{array}{c}798 \\
(16.93 \%)\end{array}$ & $\begin{array}{c}771 \\
(14.88 \%)\end{array}$ & $\begin{array}{c}105 \\
(2.01 \%)\end{array}$ & $\begin{array}{c}0 \\
(0 \%)\end{array}$ & $\begin{array}{c}0 \\
(0 \%)\end{array}$ & $\begin{array}{c}2091 \\
(3.13 \%)\end{array}$ \\
\hline 2003 & $\begin{array}{c}0 \\
(0 \%)\end{array}$ & $\begin{array}{c}7 \\
(0.03 \%) \\
\end{array}$ & $\begin{array}{c}58 \\
(2.87 \%) \\
\end{array}$ & $\begin{array}{c}274 \\
(5.81 \%)\end{array}$ & $\begin{array}{c}97 \\
(1.87 \%) \\
\end{array}$ & $\begin{array}{c}0 \\
(0 \%)\end{array}$ & $\begin{array}{c}0 \\
(0 \%)\end{array}$ & $\begin{array}{c}0 \\
(0 \%)\end{array}$ & $\begin{array}{c}436 \\
(0.65 \%) \\
\end{array}$ \\
\hline Total & $\begin{array}{c}18587 \\
(27.8 \%)\end{array}$ & $\begin{array}{c}24426 \\
(36.5 \%)\end{array}$ & $\begin{array}{c}2024 \\
(3.03 \%)\end{array}$ & $\begin{array}{c}4713 \\
(7.05 \%)\end{array}$ & $\begin{array}{c}5183 \\
(7.76 \%)\end{array}$ & $\begin{array}{c}5236 \\
(7.84 \%)\end{array}$ & $\begin{array}{c}4454 \\
(6.67 \%)\end{array}$ & $\begin{array}{c}2203 \\
(3.30 \%)\end{array}$ & $\begin{array}{l}66826 \\
(100 \%)\end{array}$ \\
\hline
\end{tabular}


tries has slowed down or even stopped, probably due to implementation of appropriate preventive measures $[17,18]$. Comparative analysis of epidemiological data is hindered by the lack of regular screening of the Polish pediatric population.

The aim of this study was to analyze the prevalence of overweight and obesity among selected age categories of children from Gdansk, on the basis of 1992-2012 data collected by the local Center for the Promotion of Children's Health and Fitness.

\section{Material and methods}

The analysis included data on body weight and height collected within the framework of two screening programs carried out by the Center for the Promotion of Children's Health and Fitness (CPCHF): "Your Child's Healthy Life" and "Healthy Student". CPCHF is a public institution, financed by the city of Gdansk.

Overall, the data of 70,329 children were analyzed, including 46,660 children between 6 and 7 years of age participating in the "Your Child's Healthy Life" program between 1994 and 2010, and the measurements of 23,669 children aged

A

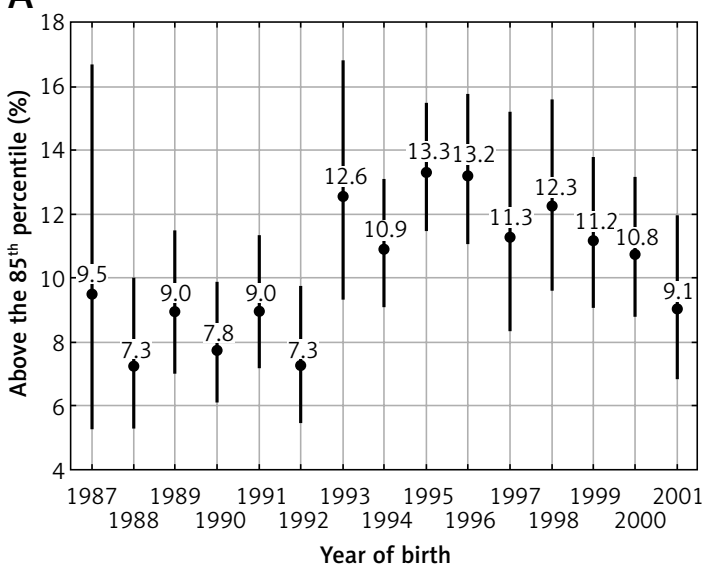

C

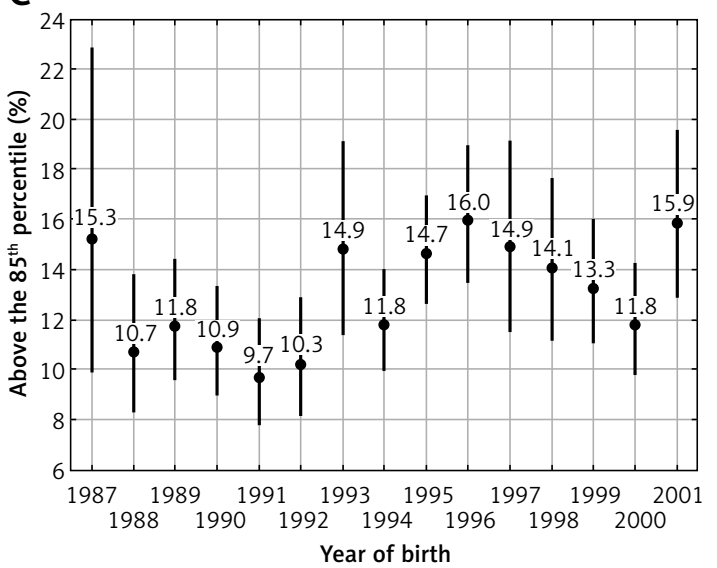

between 8 and 13 years who took part in the "Healthy Student" program between 1998 and 2012. The protocol of the study was approved by the Local Bioethics Committee at the Medical University of Gdansk. All the children were examined after obtaining written consent from their parents (legal caregivers) and in their presence (in the case of 6-7-year-old children).

Body height was measured to the nearest $1 \mathrm{~mm}$, with the children standing barefoot in a stretched (Frankfurt) position. Body weight was determined to the nearest $50 \mathrm{~g}$, with the children barefoot and dressed in their underwear or gym outfits.

The age of the children, expressed in a decimal system, was calculated as the difference between the date of measurement and the date of birth, according to Malina and Bouchard [19].

The percentile categories of body height, body weight, and body mass index (BMI) were determined on the basis of actual reference charts for Polish children and adolescents [20].

\section{Statistical analysis}

Percentiles of BMI and z-scores were calculated on the basis of $L, M$, and $S$ parameters, as de-

B

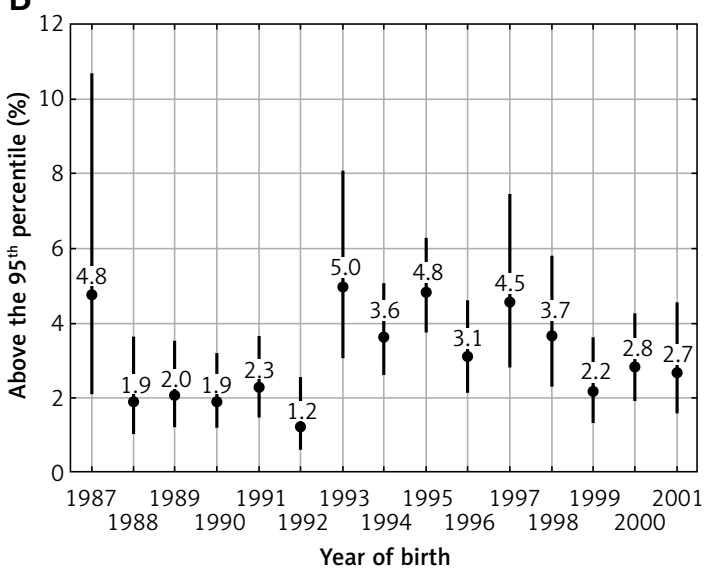

D

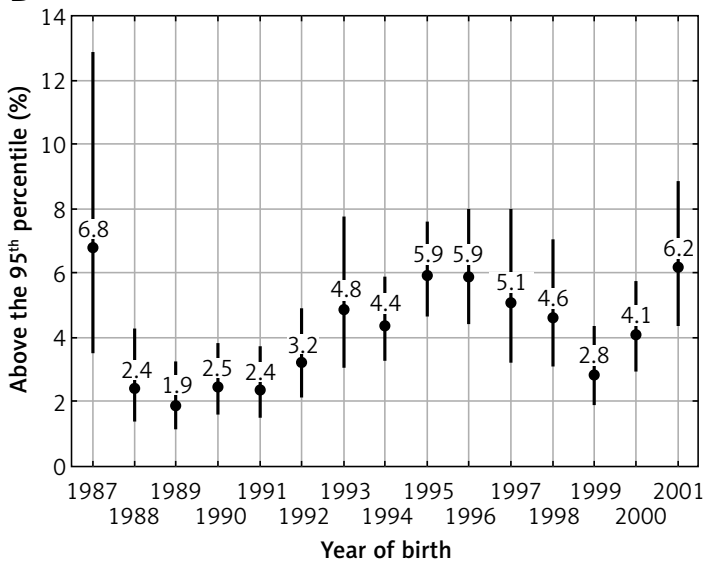

Figure 1. Prevalence of overweight (above the $85^{\text {th }}$ percentile) and obesity (above the $95^{\text {th }}$ percentile) among 6-year-old boys (A, B) and girls (C, D) 
scribed by Cole [1]. Percentages of children who did not fall into respective BMI categories were presented with the Wilson confidence intervals. The results were compared with Pearson's $\chi^{2}$ test or Fisher's exact test. All the calculations were carried out in the R 2.15.1 environment, with the threshold of statistical significance set at $p \leq 0.05$.

\section{Results}

\section{Characteristics of study group}

Basic characteristics of the studied population, stratified according to children's age and year of examination, are presented in Table I. Due to the very low fraction of 8-year-old children $(n=2,024$, $3.03 \%$ ), which resulted from the specifics of the screening protocol, this group was not included in further analyses. Although the group of 13-yearold children also constituted a small fraction of the entire examined population (3.30\%), it still corresponded to about $10 \%$ of all 13 -year-olds from Gdansk, and thus was included in our analysis. Moreover, a predominance of 6- and 7-yearold children, corresponding to more than $60 \%$ of the study group, is worth noting. This is associated with longer duration of screening in this age

A

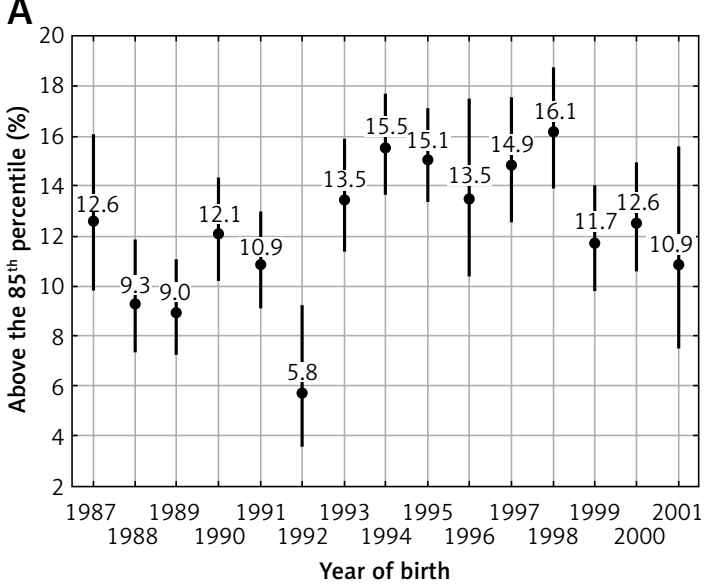

C

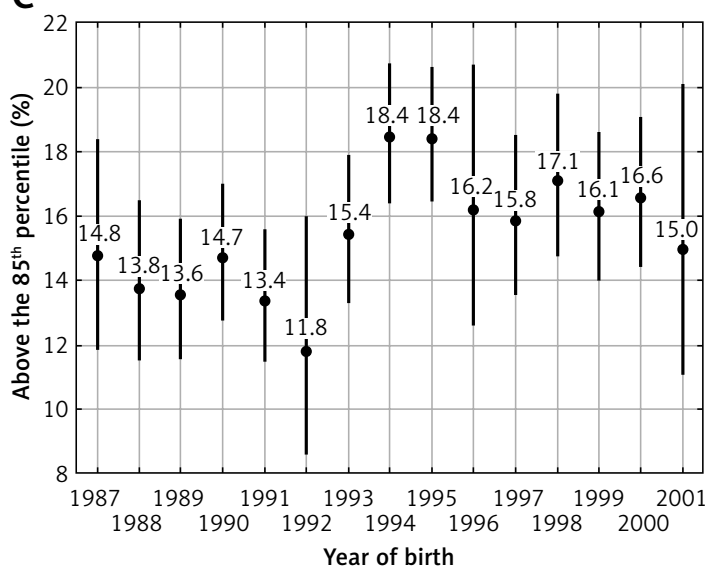

category and the specificity of examination of 8- to 13-year-old children. The fractions of girls and boys were $50.46 \%$ and $49.54 \%$ of the study group, respectively.

\section{Prevalence of overweight and obesity}

On the basis of data on participants' age, body weight and body height, the gender-specific percentile values of BMI were assigned to each age category. The data presented here include a group of 6- to 7- and 9- to 13-year-old children.

The prevalence of overweight and obesity in the study group, stratified according to gender and age, is presented in Figures 1-5. The genderand age-specific values of the $85^{\text {th }}$ and $95^{\text {th }}$ percentile of $\mathrm{BMI}$ were determined from the percentile charts [20].

Due to availability of data from the CPCHF's screening programs, the duration of follow-up was the longest (i.e. 17 years) in the case of 6-7-yearold children. In contrast, the shortest, 6-year long, follow-up was available for 13-year-old children.

Statistical analysis revealed that the prevalence of overweight and obesity among children from various age categories differed significantly

B

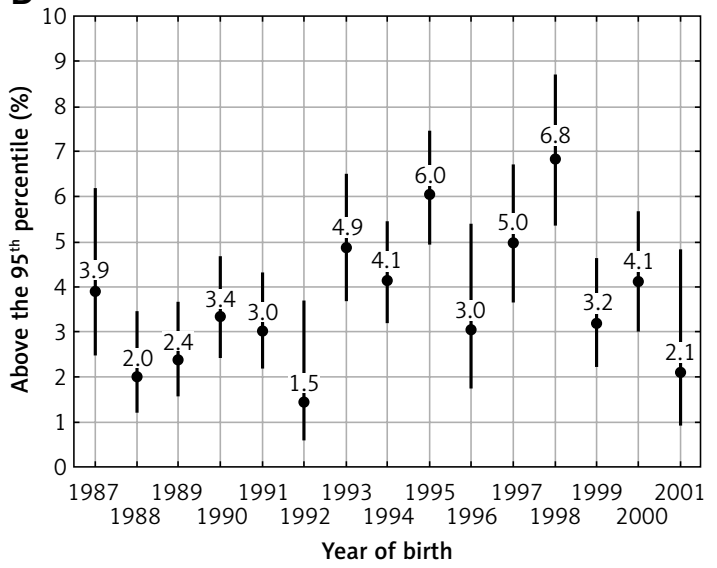

D

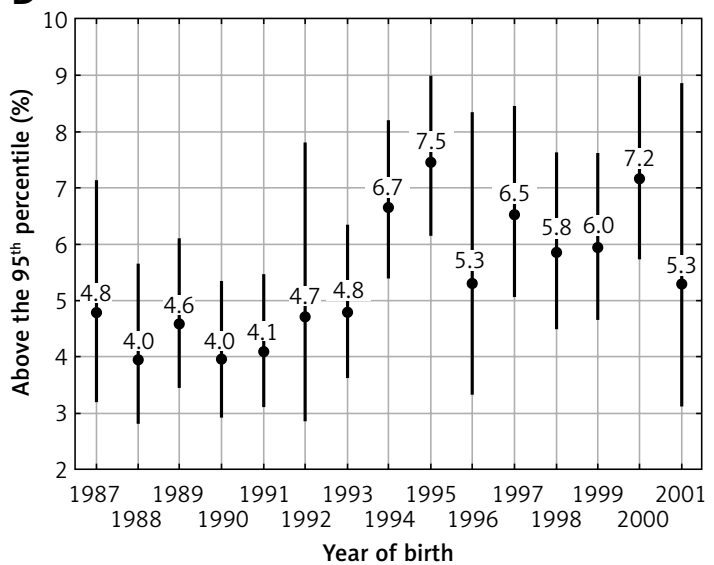

Figure 2. Prevalence of overweight (above the $85^{\text {th }}$ percentile) and obesity (above the $95^{\text {th }}$ percentile) among 7-year-old boys (A, B) and girls (C, D) 
depending on the year of examination. A growing tendency, lasting for 4-5 years, was observed in the case of 6-7-year-old children born in 19931998 and examined between 1999 and 2005. A similar tendency was documented in 12-yearold participants, examined between 2005 and 2010. However, both tendencies were normalized or reversed in subsequent years. Aside from that, we did not identify any constant trend to increase or decrease in the prevalence of overweight and obesity in any of the studied age groups.

However, we revealed an age-related increase in the prevalence of overweight and obesity. While it was observed throughout all consecutive age categories in boys, an increase in the prevalence of excess body weight in girls was documented solely until puberty (about 10 years of age), with a subsequent decrease, more pronounced in the case of overweight than in obesity.

We revealed statistically significant genderspecific differences in the prevalence of overweight and obesity. Overweight and obesity were significantly more frequent in girls than in boys from all age categories, except 12- and 13-yearold children, in whom no gender-specific differences were documented.

A

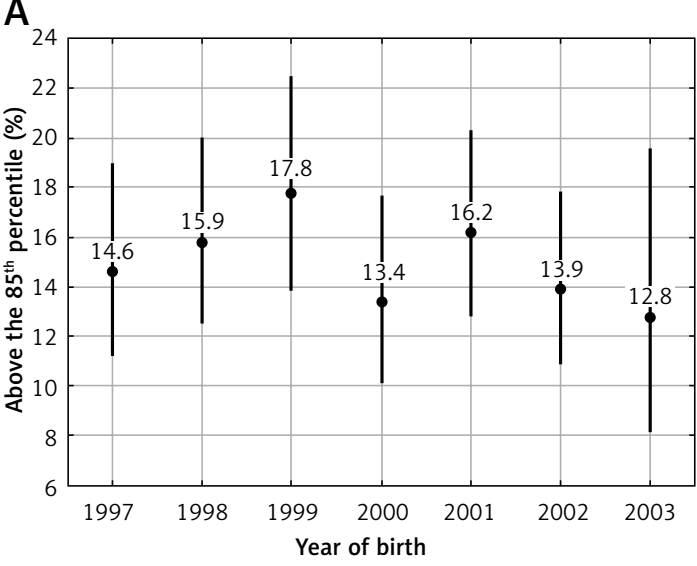

C

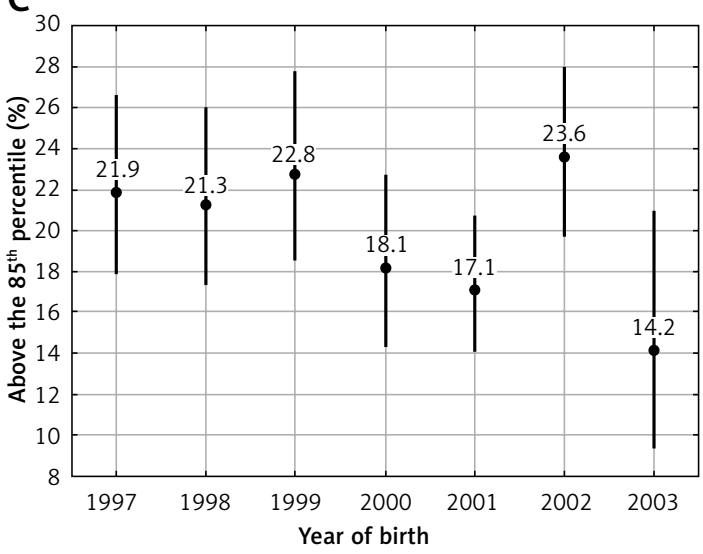

\section{Discussion}

Long-term studies revealed an increasing tendency in the prevalence of overweight and obesity in children and adolescents from developed and developing countries. The situation in Poland is similar as in other Central European countries [21, 22].

Searching through the available literature we found sparse nationwide epidemiologic reports and a few studies analyzing changes in body weight of children and adolescents from various regions of Poland $[23,24]$. They documented significant changes in both mean and maximum values of these parameters. Unfortunately, respective changes in BMI were not reported in these papers.

We did not confirm the previously reported growing tendency in the prevalence of overweight and obesity among children. Although a slight upward tendency was documented among 6- to 7-year-old children born between 1987 and 1999, it was substantially corrected in subsequent years. Chrzanowska et al. [24] documented a considerable increase in mean body weight on comparative analysis of data from children examined in 1971 and 1983; however, despite longer interval be-

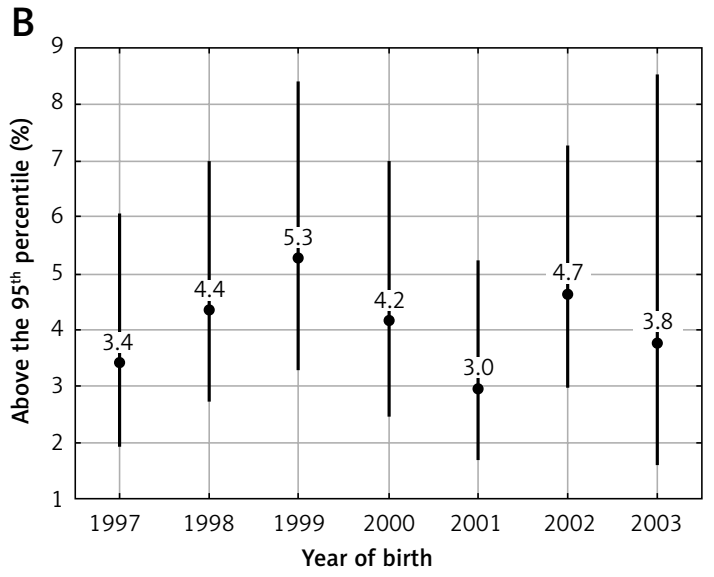

D

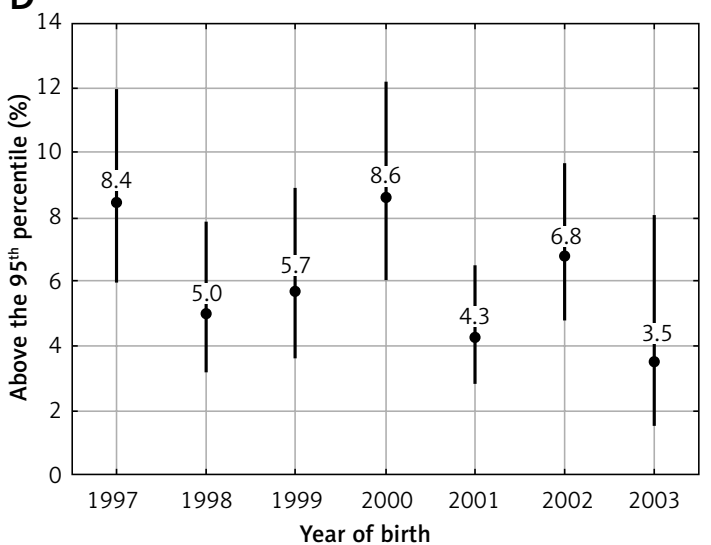

Figure 3. Prevalence of overweight (above the $85^{\text {th }}$ percentile) and obesity (above the $95^{\text {th }}$ percentile) among 9-year-old boys (A, B) and girls (C, D) 
A

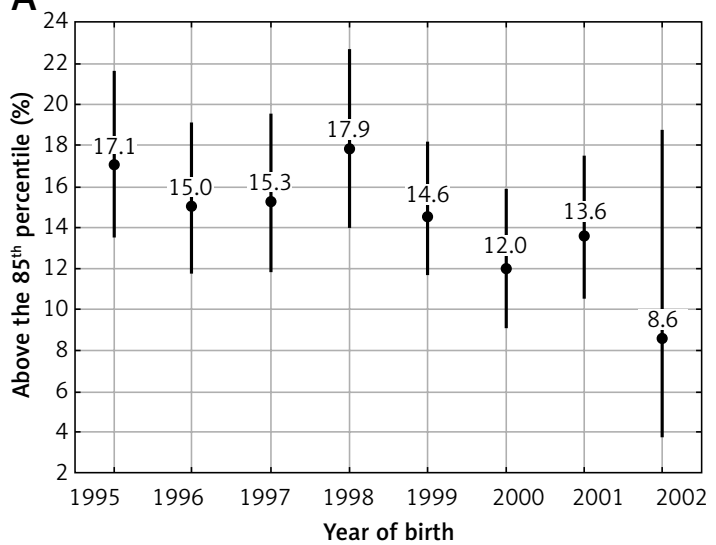

C

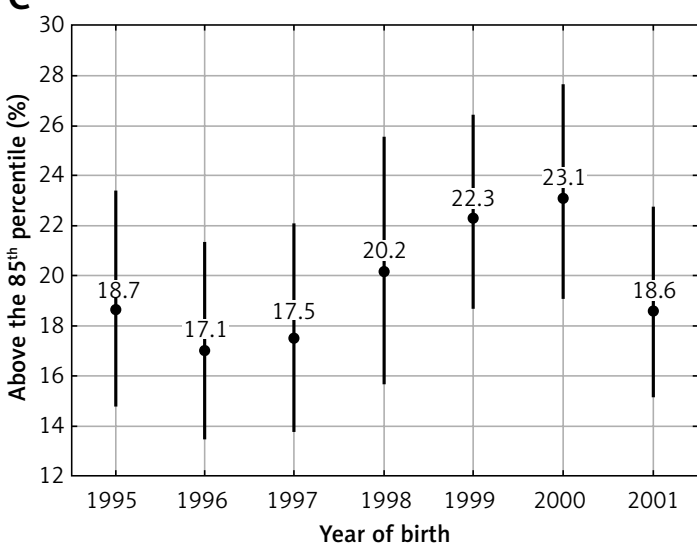

B

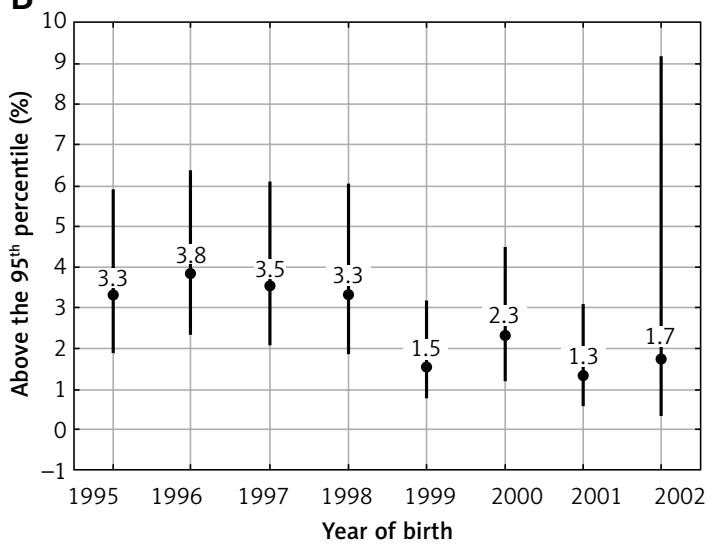

D

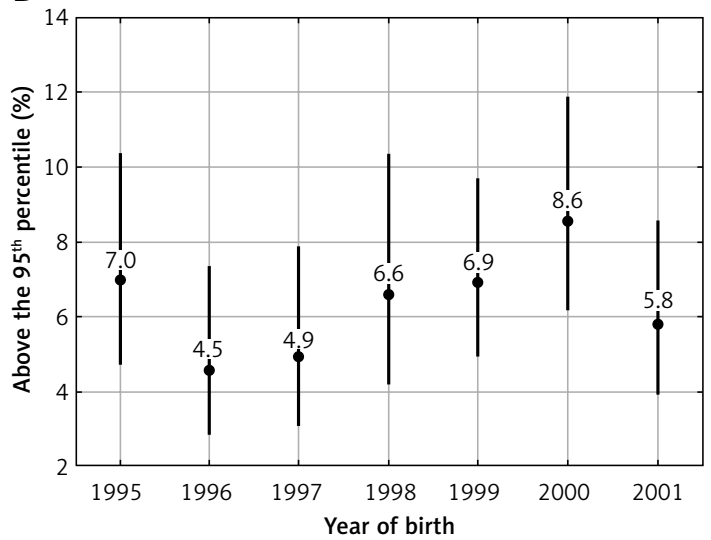

Figure 4. Prevalence of overweight (above the $85^{\text {th }}$ percentile) and obesity (above the $95^{\text {th }}$ percentile) among 11 -year-old boys (A, B) and girls (C, D)

tween the studies, she reported markedly less pronounced differences in body weight of individuals examined in 1983 and 2000. Also, another Polish study [25] revealed that the increase in mean body weight and height of subjects examined in the 1970s and 1980s was more pronounced than in subsequent decades. As our study included data of children born after 1987, it probably did not cover this period of secular increase in physical development. Nevertheless, it should be noted that data from many highly developed countries, and the results of Polish regional studies [23, 24], suggest that the problem in question still existed, albeit at a markedly lower rate, also in 1990s and in the first decade of the $21^{\text {st }}$ century [25]. Comparing those data to available similar data from other CEE countries shows similarity in the lack of tendency of obesity increase in younger children (preschool in the Czech Republic) [26]. Differences were observed in adolescents. Increase of overweight and/or obesity was observed in some age groups in youth from Slovakia and the Czech Republic [22, 27].

The discrepancies between our findings and literature evidence may have several potential reasons. For example, the follow-up period of our 10-13-year-old children was too short to reveal any longitudinal changes. As a result, we did not observe any secular trend in the anthropometric parameters of participants from this age category, and a decrease in the prevalence of overweight and obesity was occasionally documented. During a 17-year observation of children aged 6 and 7, we identified a period characterized by a secular increase in body weight. The increased prevalence of overweight and obesity was observed in boys and girls born between 1999 and 2005. Although this tendency was not documented in subsequent years, a periodic character of changes could still be observed. However, this phenomenon did not occur universally across the whole studied population. Perhaps this resulted from the quality of available data, namely from the CPCHF's organization of work and too short follow-up period of children older than 6-7 years of age.

A decrease in the prevalence of overweight can result from a variety of reasons. The prevalence of excess body weight among children decreases proportionally to the number of social or media campaigns, and educational activities addressed to school teachers, parents and the children themselves. However, data from neighboring states and 
A

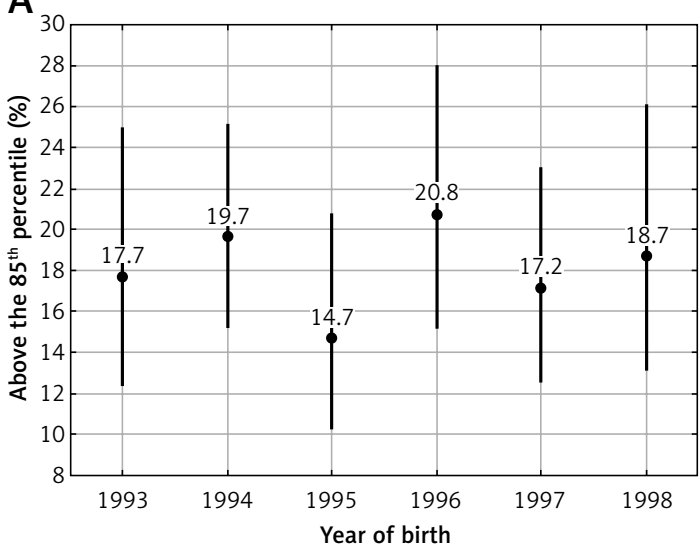

C

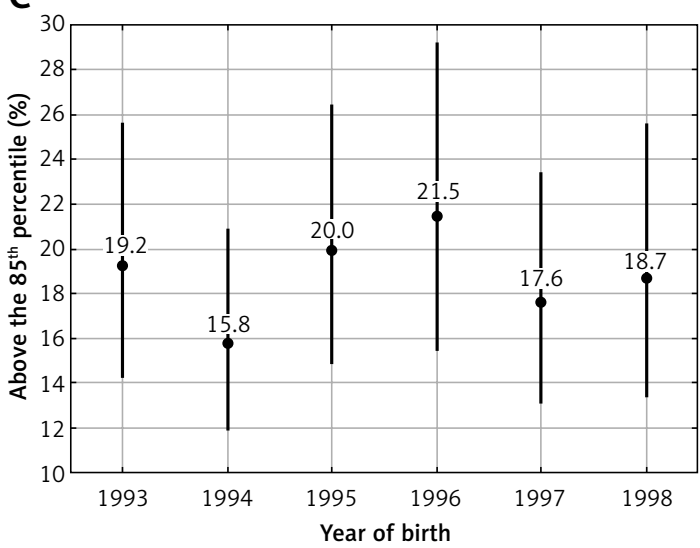

B

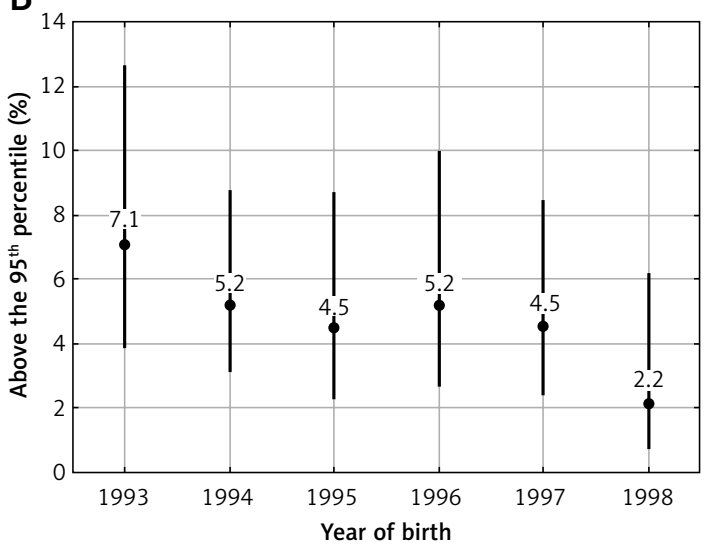

D

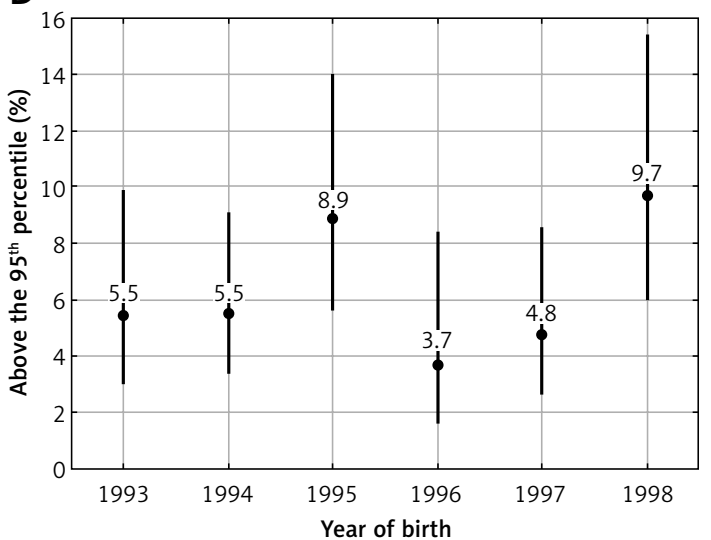

Figure 5. Prevalence of overweight (above the $85^{\text {th }}$ percentile) and obesity (above the $95^{\text {th }}$ percentile) among 13-year-old boys (A, B) and girls (C, D)

countries characterized by a higher level of economic development suggest that the complete attenuation of the secular trend observed in Poland is unlikely. Nevertheless, it could be at least normalized by early implementation of the preventive measures mentioned above.

The age-related increase in the prevalence of excess body weight is another problem identified by our study. Moreover, we revealed gender-specific differences in this parameter. These differences may result from the influence of both intrinsic and extrinsic factors, among them sexual maturation and gender-specific distribution of body fat, which is indirectly reflected by BMI. Also the environmental impact should be considered, as patterns of an ideal male and female figure exist in public opinion. Noticeably, our findings are consistent with data from other regions of Poland [23]. Similar results were found in several studies including studies from the Czech Republic, showing a large difference in prevalence of obesity between sexes [21, 28].

In conclusion, this study did not identify any constant trend in the prevalence of overweight and obesity among 6- to 13-year-old children from Gdansk. Nevertheless, a periodic increase in the prevalence of excess body weight was documented among 6-, 7-, and 12-year-old children born between 1993 and 1997. While the prevalence of overweight in boys increased with age, a similar tendency was documented solely in prepubertal girls. The prevalence of obesity increased in puberty in boys, and remained relatively stable throughout all developmental stages of girls. The prevalence of excess body weight was higher in girls than in boys.

\section{Conflict of interest}

The authors declare no conflict of interest.

\section{References}

1. Cole TJ. Secular trends in growth. Proc Nutr Soc 2000; 59: 317-24.

2. Danubio ME, Sanna E. Secular changes in human biological variables in Western countries: an updated review and synthesis. J Anthropol Sci 2008; 86: 91-112.

3. Roelants M, Hauspie R, Hoppenbrouwers K. References for growth and pubertal development from birth to 21 years in Flanders, Belgium. Ann Hum Biol 2009; 36: 680-94.

4. Roy JR, Chakraborty S, Chakraborty TR. Estrogen-like endocrine disrupting chemicals affecting puberty in humans - a review. Med Sci Monit 2009; 15: RA137-45. 
5. Hulanicka B, Gronkiewicz L, Koniarek J. Effect of familial distress on growth and maturation of girls: a longitudinal study. Am J Hum Biol 2001; 13: 771-6.

6. Cole TJ. The secular trend in human physical growth: a biological view. Econ Hum Biol 2003; 1: 161-8.

7. Himes JH, Dietz WH. Guidelines for overweight in adolescent preventive services: recommendations from an expert committee. The Expert Committee on Clinical Guidelines for Overweight in Adolescent Preventive Services. Am J Clin Nutr 1994; 59: 307-16.

8. Daniels SR, Khoury PR, Morrison JA. The utility of body mass index as a measure of body fatness in children and adolescents: differences by race and gender. Pediatrics 1997; 99: 804-7.

9. Must A, Dallal GE, Dietz WH. Reference data for obesity: 85th and 95th percentiles of body mass index (wt/ht2) and triceps skinfold thickness. Am J Clin Nutr 1991; 53 : 839-46.

10. Finucane MM, Stevens GA, Cowan MJ, et al. National, regional, and global trends in body-mass index since 1980: systematic analysis of health examination surveys and epidemiological studies with 960 country-years and 9.1 million participants. Lancet 2011; 377: 557-67.

11. Waxman A, World Health Assembly. WHO global strategy on diet, physical activity and health. Food Nutr Bull 2004; 25: 292-302.

12. Lissner L, Wijnhoven TMA, Mehlig K, et al. Socioeconomic inequalities in childhood overweight: heterogeneity across five countries in the WHO European Childhood Obesity Surveillance Initiative (COSI-2008). Int J Obes 2016; 40: 796-802.

13. Ulijaszek SJ, Koziel S. Nutrition transition and dietary energy availability in Eastern Europe after the collapse of communism. Econ Hum Biol 2007; 5: 359-69.

14. Zatonski W, Campos H, Willett W. Rapid declines in coronary heart disease mortality in Eastern Europe are associated with increased consumption of oils rich in alpha-linolenic acid. Eur J Epidemiol 2008; 23: 3-10.

15. Bandosz P, O'Flaherty $M$, Drygas W, et al. Decline in mortality from coronary heart disease in Poland after socioeconomic transformation: modelling study. BMJ 2012; 344: d8136.

16. Lobstein T, Baur L, Uauy R; IASO International Obesity Task Force. Obesity in children and young people: a crisis in public health. Obes Rev 2004; 5 Suppl 1: 4-104.

17. Ghomari-Boukhatem H, Bouchouicha A, Mekki K, Chenni K, Belhadj M, Bouchenak M. Blood pressure, dyslipidemia and inflammatory factors are related to body mass index in scholar adolescents. Arch Med Sci 2017; 13: 46-52.

18. Lissner L, Sohlstrom A, Sundblom E, Sjoberg A. Trends in overweight and obesity in Swedish schoolchildren 1999-2005: has the epidemic reached a plateau? Obes Rev 2010; 11: 553-9.

19. Malina RM, Bouchard C. Growth, maturation and physical activity. $2^{\text {nd }}$ ed. HKP, Champaign 2004.

20. Kulaga Z, Litwin M, Tkaczyk M, et al. Polish 2010 growth references for school-aged children and adolescents. Eur J Pediatr 2011; 170: 599-609.

21. Ng M, Fleming T, Robinson M, et al. Global, regional, and national prevalence of overweight and obesity in children and adults during 1980-2013: a systematic analysis for the Global Burden of Disease Study 2013. Lancet 2014; 384: 766-81.

22. Sigmund E, Sigmundová D, Badura P, Kalman M, Hamrik Z, Pavelka J. Temporal trends in overweight and obesity, physical activity and screen time among Czech adolescents from 2002 to 2014: A National Health Behaviour in School-Aged Children study. Int J Environ Res Public Health 2015; 12: 11848-68.

23. Krawczynski M, Walkowiak J, Krzyzaniak A. Secular changes in body height and weight in children and adolescents in Poznan, Poland, between 1880 and 2000. Acta Paediatr 2003; 92: 277-82.

24. Chrzanowska M, Koziel S, Ulijaszek SJ. Changes in BMI and the prevalence of overweight and obesity in children and adolescents in Cracow, Poland, 1971-2000. Econ Hum Biol 2007; 5: 370-8.

25. Bac A, Wozniacka R, Matusik S, Golec J, Golec E. Prevalence of overweight and obesity in children aged 6-13 years-alarming increase in obesity in Cracow, Poland. Eur J Pediatr 2012; 171: 245-51.

26. Sigmund E, Sigmundová D, Badura P, Trhlíková L, Madarasová Gecková A. Time trends: a ten-year comparison (2005-2015) of pedometer-determined physical activity and obesity in Czech preschool children. BMC Public Health 2016; 16: 560 .

27. Zvonar M, Vadasova B, Smerecka V, Cech P, Ruzbarsky P. Overweight and Obesity in Slovak High School Students. The European Proceedings of Social \& Behavioural Sciences. EpSBS http://dx.doi.org/10.15405/ epsbs.2016.06.2.

28. Sigmundová D, Sigmund E, Hamrik Z, Kalman M. Trends of overweight and obesity, physical activity and sedentary behaviour in Czech schoolchildren: HBSC study. Eur J Public Health 2014; 24: 210-5. 